\title{
Crystalline Photochromism of 2-Propynylallene Derivatives
}

\author{
Koichi Tanaka, ${ }^{*}$ Akihiro Tomomori, and Janet L. Scott ${ }^{*, 1}$ \\ Department of Applied Chemistry, Faculty of Engineering, Kansai University, Suita, Osaka 564-8680 \\ ${ }^{1}$ Center for Green Chemistry, Monash University, Clayton, Victoria, 3800, Australia
}

Received June 28, 2004; E-mail: ktanaka@ipcku.kansai-u.ac.jp

\begin{abstract}
Some 2-propynylallene derivatives exhibited color change from pale-yellow to green upon photoirradiation with visible light in the solid state. The green color disappeared either by heating or dissolving into solvents. The photochromism of 2-propynylallene derivatives depends largely on the substituents on the aromatic rings. Crystallographic analysis indicates that the overlap of the $\pi$ systems of the fluorene moiety in the photochromic crystals allow photoinduced charge-transfer interactions in the solid-state.
\end{abstract}

Organic photochromic compounds have received much attention in recent years because of their potential applications, such as information storage, electronic display systems, optical switching devices, ophthalmic glasses, and so on. ${ }^{1}$ Several types of organic photochromic compounds, such as naphthopyrans, spiropyrans, fulgides, and $N$-salicylideneanilines, have been discovered, and their properties have been studied mostly in solution. ${ }^{1}$ However, organic compounds showing photochromism in the crystalline state are very rare. ${ }^{2}$ It has recently been reported that diarylethenes $\mathrm{s}^{2 \mathrm{a}, 2 \mathrm{~b}}$ and $\mathrm{N}$-salicylideneanilines $^{2 \mathrm{~d}, 2 \mathrm{~g}}$ show photochromism in the single-crystalline state. We have also reported that some biindenylidene derivatives exhibit photochromism only in the solid state. ${ }^{2 \mathrm{e}, 2 \mathrm{f}}$

Recently, we found that crystals of 2-[2,7-dibromo-9(3-oxo-3-phenylprop-1-ynyl)-9H-fluoren-9-yl]-3-(fluoren-9-ylidene)-1-phenyl-2-propen-1-one (2b) quickly turn color from pale-yellow to green when exposed to visible light. ${ }^{3}$ The green crystals gradually reverted to the original pale-yellow crystals upon storage in the dark for over two weeks at room temperature, or quickly upon heating at around $60{ }^{\circ} \mathrm{C}$. The photochromism occurred reversibly at least 20 times without any decomposition. The solid-state IR spectrum of the green crystals was identical to that of the pale-yellow crystals, and no ESR signal developed upon photoirradiation. Exposure of a solution of $\mathbf{2} \mathbf{b}$ to visible light revealed no photocoloration. On the other hand, an isomeric compound, 3-(2,7-dibromofluoren-9ylidene)-2-[9-(3-oxo-3-phenylprop-1-ynyl)-9H-fluoren-9-yl]-1phenyl-2-propen-1-one (3b), did not show any photochromism. An X-ray analysis showed that the extent of overlap of the $\pi$ systems is greater in photochromic crystals (2b) than in non-photochromic ones (3b). This difference in packing allows for the drastic color change, probably due to the photoinduced charge-transfer interactions. To determine the generality of this effect, we have now prepared a variety of similar systems (1-5), Chart 1, and investigated their photochromic properties in the solid state.

\section{Results and Discussion}

2-Propynylallene derivatives (1-5) were synthesized by a similar method for $\mathbf{1 a}, \mathbf{2 b}$, and $\mathbf{3 b} .^{3,4}$ Table 1 gives the results of an investigation of photochromism for 2-propynylallene crystals by irradiating using a 150-W halogen-lamp for 5 min. 2-Propynylallene (1a) did not show any photochromism. The $o$ - and $p$-tolyl derivatives of $\mathbf{1 a}(\mathbf{1 b}$ and $\mathbf{1 d})$ showed photochromism from pale-yellow to green upon photoirradiation, whereas the $m$-isomer did not. All of the methoxy-phenyl derivatives of $\mathbf{1 a}(\mathbf{1 e}, \mathbf{1 f}$, and $\mathbf{1 g})$ showed photochromism, and the stability of the colored form of the $m$-isomer (bleaching time: $>336 \mathrm{~h}$ ) was far greater than those of $o$ - (bleaching time: $3 \mathrm{~h}$ ) and $p$-isomers (bleaching time: $2 \mathrm{~h}$ ). The $\lambda$ maximum of the UV spectra of the colored form shifted towards longer wavelengths in the order of $o-, m-$, and $p$-isomer. On the contrary, all of the crystals of chlorophenyl derivatives $(\mathbf{1 h}, \mathbf{1 i}$, and 1j) having electron-withdrawing groups did not show any photocoloration. These observations suggest that the electronic interactions between the aryl groups of $\mathbf{1}$ play an important role for the photochromism in the solid state.

The halogen-substituted 2-propynylallene derivatives $(\mathbf{2}, \mathbf{3}$, 4, and 5) were also synthesized, and their photochromicity was investigated. Interestingly, the position of the halogen substituents on the fluorene ring affects the photochromic properties. For example, 2-propynylallenes with one 2,7-dihalofluorene (2a and $\mathbf{2} \mathbf{b})$ showed photochromism, whereas isomeric compounds (3a and $\mathbf{3 b}$ ) did not. The 2-propynylallenes with two 2-halofluorene (4a and $\mathbf{4 b}$ ) also showed photochromism in the solid state (Fig. 1), although the 2-propynylallenes with two 2,7-dihalo-fluorene (5a and $\mathbf{5 b}$ ) did not show any photochromism.

The 2-propynylallenes (1b, 1d, 1e, 1f, 1g, 2a, 2b, 4a, and 4b) showed thermally reversible photochromism with the bleaching times listed in Table 1 , and the bleaching rate depended on the substitution on the aromatic rings. For example, the pale-yellow crystals of $\mathbf{4} \mathbf{b}$ were quickly converted to green crystals upon 5 min of irradiation by a halogen lamp, and the green color faded slowly $(24 \mathrm{~h})$ in the dark at room temperature, or quickly upon heating at around $60{ }^{\circ} \mathrm{C}$. Figure 2 shows the UV spectra of $\mathbf{4 b}$ before and after photoirradition in the solid state. However, the irradiation of $\mathbf{4 b}$ in a chloroform solution resulted in no detectable coloration.

As the photochromism in these compounds is exclusively a 


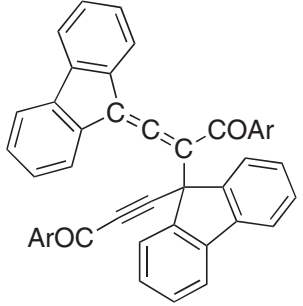

1

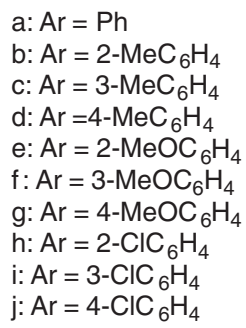

$\mathrm{a}: \mathrm{Ar}=\mathrm{Ph}$

$\mathrm{b}: \mathrm{Ar}=2-\mathrm{MeC}_{6} \mathrm{H}_{4}$

c: $\mathrm{Ar}=3-\mathrm{MeC}_{6} \mathrm{H}_{4}$

$\mathrm{d}: \mathrm{Ar}=4-\mathrm{MeC}_{6} \mathrm{H}_{4}$

$\mathrm{e}: \mathrm{Ar}=2-\mathrm{MeOC}_{6} \mathrm{H}_{4}$

$\mathrm{f}: \mathrm{Ar}=3-\mathrm{MeOC}_{6} \mathrm{H}_{4}$

h: $\mathrm{Ar}=2-\mathrm{ClC}_{6} \mathrm{H}_{4}$

$\mathrm{i}: \mathrm{Ar}=3-\mathrm{ClC}_{6} \mathrm{H}_{4}$

$\mathrm{j}: \mathrm{Ar}=4-\mathrm{ClC}_{6} \mathrm{H}_{4}$
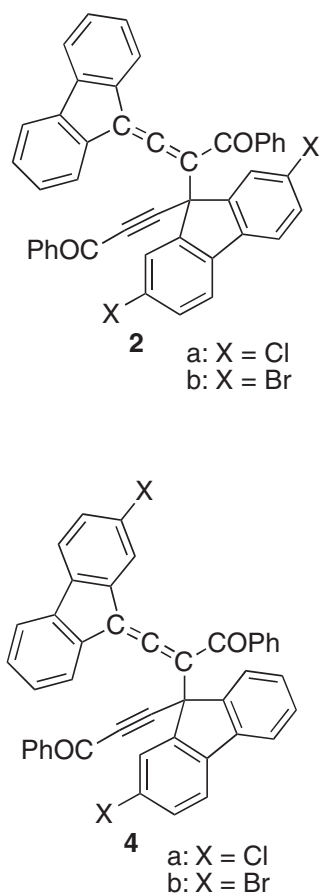

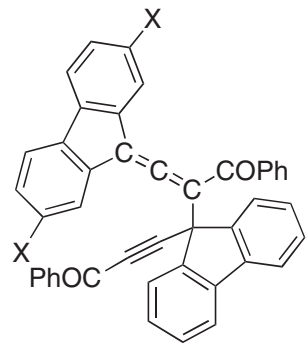

3

$\mathrm{b}: \mathrm{X}=\mathrm{Br}$

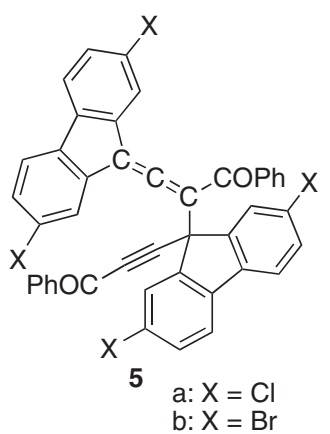

Chart 1.

Table 1. Photochromism of $\mathbf{1 - 5}$ in the Solid State

\begin{tabular}{cccc}
\hline Compound & Photochromisms & $\lambda_{\max } / \mathrm{nm}$ & Bleaching time $/ \mathrm{h}$ \\
\hline $\mathbf{1 a}$ & no & - & - \\
$\mathbf{1 b}$ & yes & 630 & 0.5 \\
$\mathbf{1 c}$ & no & - & - \\
$\mathbf{1 d}$ & yes & 580,630 & 6 \\
$\mathbf{1 e}$ & yes & 630 & 3 \\
$\mathbf{1 f}$ & yes & $600,650,750$ & $>336$ \\
$\mathbf{1 g}$ & yes & 670 & 2 \\
$\mathbf{1 h}$ & no & - & - \\
$\mathbf{1 i}$ & no & - & - \\
$\mathbf{1 j}$ & no & - & - \\
$\mathbf{2 a}$ & yes & 660 & $>336$ \\
$\mathbf{2 b}$ & yes & 660 & $>336$ \\
$\mathbf{3 a}$ & no & - & - \\
$\mathbf{3 b}$ & no & - & - \\
$\mathbf{4 a}$ & yes & 660 & 15 \\
$\mathbf{4 b}$ & yes & 660 & 24 \\
$\mathbf{5 a}$ & no & - & - \\
$\mathbf{5 b}$ & no & - & - \\
\hline
\end{tabular}

solid-state phenomenon, we turned our attention to the packing of the molecules in the crystalline form. Single-crystal structures of $\mathbf{1 d}, \mathbf{1} \mathbf{j}$, and $\mathbf{4 a}$ are reported here and compared with previously published $\mathbf{1 a},{ }^{4} \mathbf{2} \mathbf{b}$, and $\mathbf{3} \mathbf{b} .{ }^{3}$ The conformations of these 2-propynylallenes do not differ greatly from structure to structure, as illustrated in the molecular diagrams, Fig. 3. The packing of the 2-propynylallenes significantly differs from structure to structure. The overlap of "opposite end" fluorenyl $\pi$ systems of the allene and alkyne termini, noted previously, ${ }^{3}$ is a common feature of all the photoresponsive materials analysed. Thus, in all chromogenic crystals, a relatively electron- rich $\pi$ system (allene moiety) participates in face-to-face close contacts with a relatively electron-poor $\pi$ system (alkyne moiety), Figs. 4 and 5. The degree of overlap and offset varies from compound to compound, and a host disorder, as in $\mathbf{4 a}$, does not appear to compromise these $\pi \cdots \pi$ interactions, with a significant offset overlap noted in both the major and minor components, Fig. 5.

Single-crystal structure analyses of both the "dark" and "light" forms of 1d were undertaken to attempt to discern any structural differences, which might shed light on the mechanism of photochromism. As noted previously for compound $\mathbf{2} \mathbf{b},{ }^{3}$ the differences in the conformation, bond lengths or angles between the coloured and colourless crystalline forms were almost insignificant. However, a careful comparison of the bond lengths of 1d (no disorder) in coloured (light) and uncoloured (dark) forms indicate that the greatest variation occurs in the bond lengths of the aromatic fluorenyl moieties, Fig. 6. The light-induced formation of charge-transfer complexes in the solid-state, hypothesized to be the source of colour change, would certainly result in an altered molecular geometry, particularly with regards to the bond lengths of aromatic systems participating in such interactions. The lack of any more significant bond-length changes than those indicated in Fig. 6 may indicate that the coloured (transformed) species comprise a small proportion of the total. A very low population of transformed molecules may impart significant colour, yet not be detected in a diffraction experiment where the atomic positions are determined as a weighted average.

Thus, in the solid-state, photochromic compounds exhibit an allene-to-alkyne terminus overlap at the optimum $\pi \cdots \pi$ interaction distances with an interplanar spacing of 3.4-3.6 $\AA$, while non-photochromic complexes either show no $\pi$ overlap at all, $\mathbf{1 a},{ }^{3}$ or where this does occur, donor-acceptor type inter- 

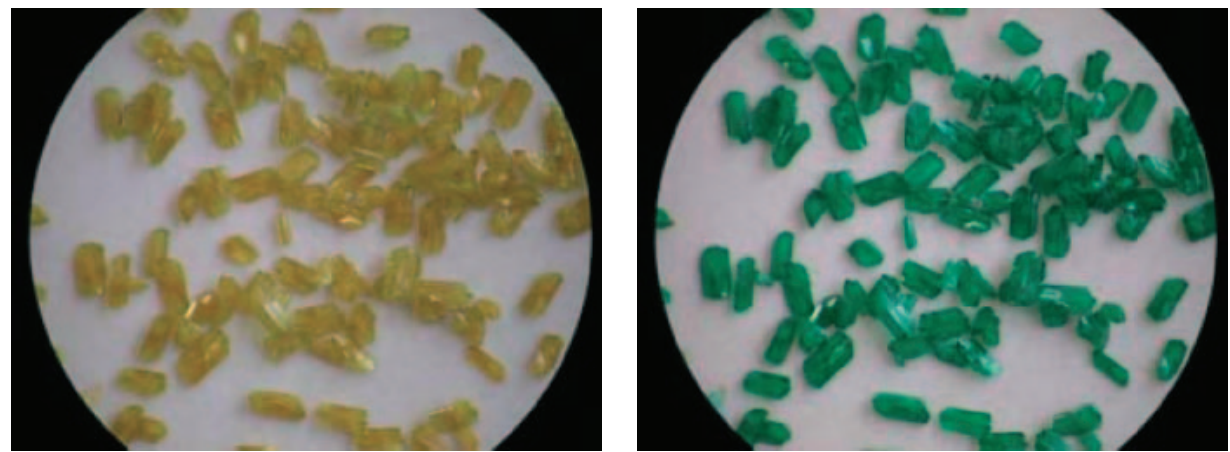

Fig. 1. Photographs of crystals of $\mathbf{4} \mathbf{b}$ before (left) and after photoirradition (right).

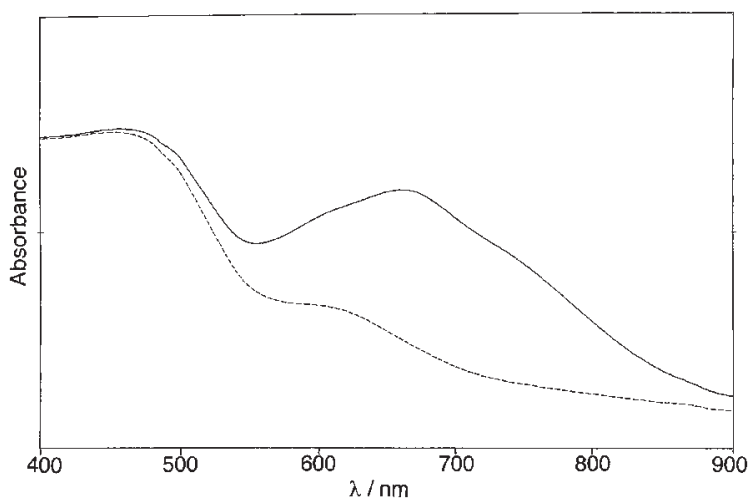

Fig. 2. UV spectra of $\mathbf{4 b}$ before (bottom) and after photoirradiation (top) in the solid state.

actions are militated against by modulation of the electronic characteristics of the $\pi$ systems by, for example, electronwithdrawing substituents $(\mathbf{1 h}-\mathbf{1 i}, \mathbf{3 a}, \mathbf{3 b})$. The hypothesis that photochromism in this class of compounds is the result of charge-transfer interactions facilitated by the overlap of fluorenyl $\pi$ systems is supported by single-crystal studies.

\section{Experimental}

General. The melting points were recorded on a Yanaco MP-3 melting apparatus and were not corrected. IR spectra were recorded on a JASCO FTIR-200 spectrometer in Nujol mulls. ${ }^{1} \mathrm{H}$ NMR spectra were recorded on a JEOL Lambda-300 spectrometer for solutions in $\mathrm{CDCl}_{3}$ with tetramethylsilane (TMS) as an internal standard. UV-vis spectra were recorded on a Shimadzu MPS-2000 spectrometer.

Photochromic Measurement. Before a measurement, crystalline powders of 2-propynylallenes were stored in the dark at $25{ }^{\circ} \mathrm{C}$. Photo-coloration was carried out by irradiating crystalline powders of 2-propynylallenes using a 150-W halogen-lamp (Cold Spot, PICL-NBX, Nippon P. I. Co. Ltd.) at room temperature. UV-vis spectra were monitored by a Shimadzu MPS-2000 spectrometer at $25^{\circ} \mathrm{C}$.

Preparation of 2-Propynylallenes: 2-propynylallenes (1-5) were prepared by a similar method for $\mathbf{1 a} .^{3,4}$

1b: colorless prisms, $\mathrm{mp}$ : thermal rearrangement ${ }^{4}$ occurred upon heating at $185{ }^{\circ} \mathrm{C}$ (DSC), IR (Nujol) 2207 (C $\left.\equiv \mathrm{C}\right), 1937$ $(\mathrm{C}=\mathrm{C}=\mathrm{C}), 1673,1637(\mathrm{C}=\mathrm{O}) \mathrm{cm}^{-1} ; \mathrm{UV}\left(\mathrm{CHCl}_{3}\right) \lambda_{\max } / \mathrm{nm}(\varepsilon)$ 259 (67700), 314 (19900); ${ }^{1} \mathrm{H}$ NMR (300 MHz, $\mathrm{CDCl}_{3}$ ) $\delta 6.61-$ $7.93(\mathrm{~m}, 24 \mathrm{H}), 3.21(\mathrm{~s}, 3 \mathrm{H}), 2.41(\mathrm{~s}, 3 \mathrm{H})$. Anal. Calcd for $\mathrm{C}_{46} \mathrm{H}_{30} \mathrm{O}_{2}$ (614.73): C, 89.88; H, 4.92\%. Found: C, 89.58; H, $4.75 \%$. 1c: pale-yellow prisms, mp: thermal rearrangement occurred upon heating at $207{ }^{\circ} \mathrm{C}$ (DSC), IR (Nujol) 2195 (C $\left.\equiv \mathrm{C}\right), 1928$ $(\mathrm{C}=\mathrm{C}=\mathrm{C}), 1662,1636(\mathrm{C}=\mathrm{O}) \mathrm{cm}^{-1} ; \mathrm{UV}\left(\mathrm{CHCl}_{3}\right) \lambda_{\max } / \mathrm{nm}(\varepsilon)$ 240 (47400), 260 (67400), 312 (20900); ${ }^{1} \mathrm{HNMR}(300 \mathrm{MHz}$, $\left.\mathrm{CDCl}_{3}\right) \delta 6.83-7.92(\mathrm{~m}, 24 \mathrm{H}), 2.23(\mathrm{~s}, 3 \mathrm{H}), 2.12(\mathrm{~s}, 3 \mathrm{H})$. Anal. Calcd for $\mathrm{C}_{46} \mathrm{H}_{30} \mathrm{O}_{2}$ (614.73): C, 89.88; H, 4.92\%. Found: C, 89.71; H, $4.88 \%$. 1d: pale-yellow prisms, mp: thermal rearrangement occurred upon heating at $200{ }^{\circ} \mathrm{C}$ (DSC), IR (Nujol) 2202 $(\mathrm{C} \equiv \mathrm{C}), 1945(\mathrm{C}=\mathrm{C}=\mathrm{C}), 1658,1635(\mathrm{C}=\mathrm{O}) \mathrm{cm}^{-1} ; \mathrm{UV}\left(\mathrm{CHCl}_{3}\right)$ $\lambda_{\max } / \mathrm{nm}(\varepsilon) 241$ (45200), 260 (67900), 353 (3120), 315 (20700); ${ }^{1} \mathrm{HNMR}\left(300 \mathrm{MHz}, \mathrm{CDCl}_{3}\right) \delta 6.81-7.88(\mathrm{~m}, 24 \mathrm{H})$, 2.27 (s, 3H), 2.22 (s, 3H). Anal. Calcd for $\mathrm{C}_{46} \mathrm{H}_{30} \mathrm{O}_{2}$ (614.73): C, 89.88; H, 4.92\%. Found: C, 89.74; H, 4.71\%. 1e: pale-yellow
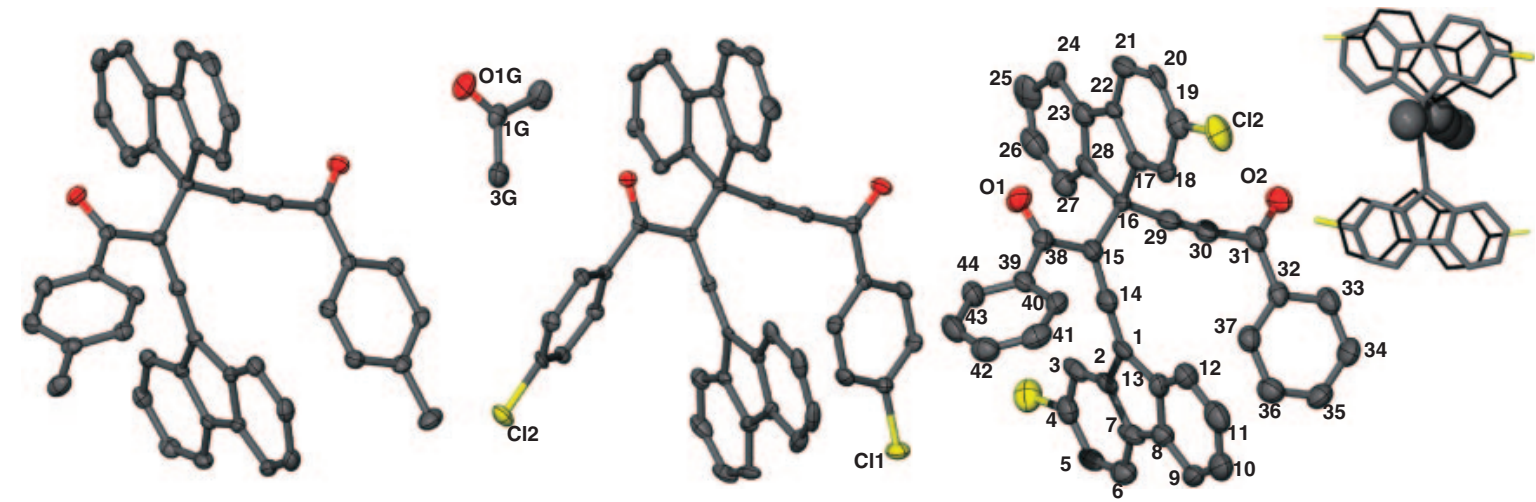

Fig. 3. Molecular diagrams of $\mathbf{1 a}$ (left), $\mathbf{1 j}$ (middle), and $\mathbf{4 a}$ (right, major component only and disordered ethyl acetate omitted): ellipsoids are depicted at the 50\% probability level and molecular numbering is the same for the skeleton of both molecules. Inset: two components of disordered $4 \mathbf{a}$ with the minor component (20\%) depicted with thin black lines (right). 

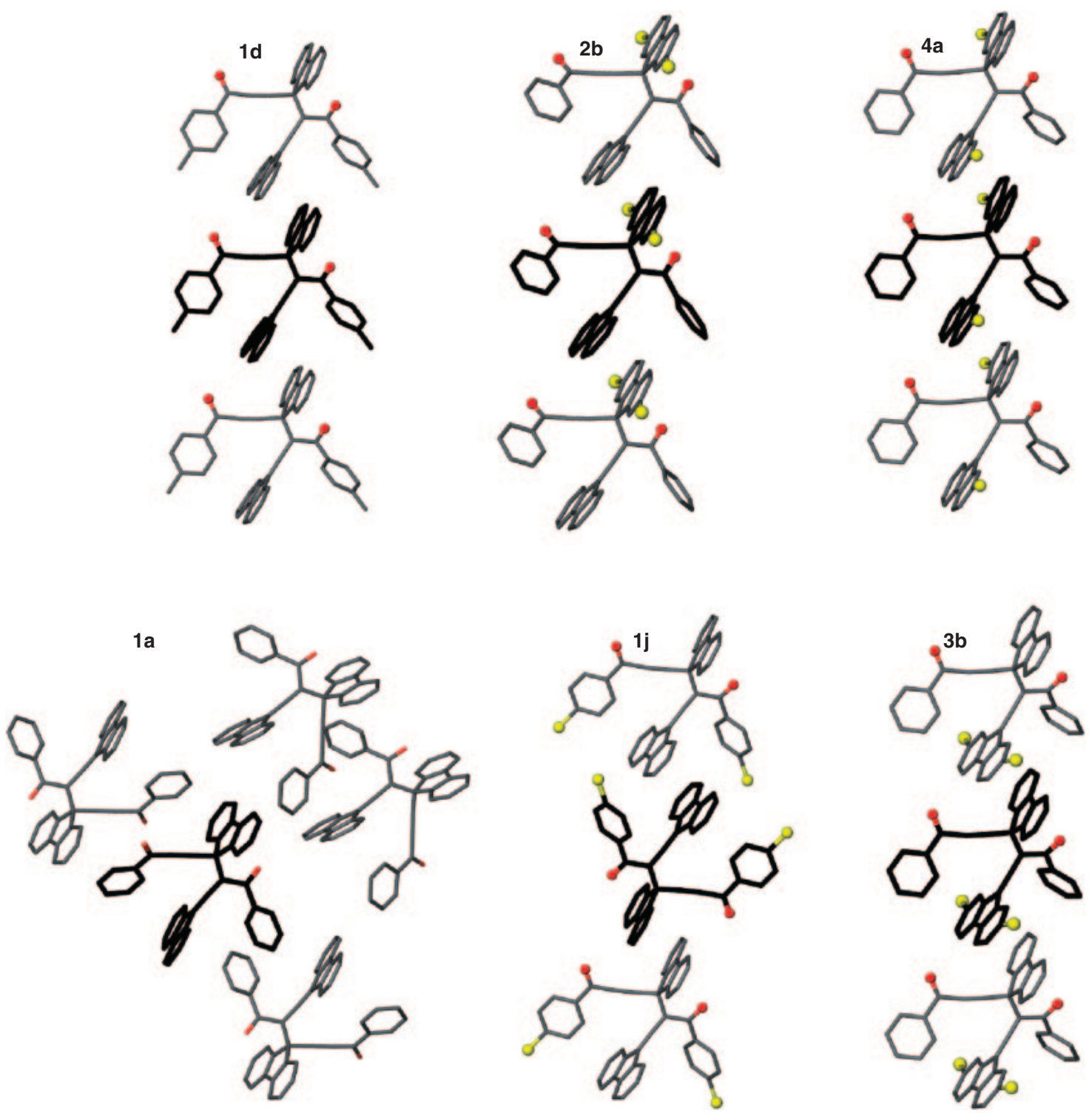

Fig. 4. In photochromic crystals, $\pi \ldots \pi$ interactions of fluorenyl $\pi$ systems yield chains of molecules with alternating donor and acceptor interactions (top). Non-photochromic compounds $\mathbf{1 a}$ and $\mathbf{1} \mathbf{j}$ show no such alternating interaction (bottom left and middle) with, respectively, no face to face $\pi \ldots \pi$ interactions of fluorenyl moieties and like to like $\pi \ldots \pi$ interactions. 3b exhibits similar packing to that observed in the photochromic compounds but the addition of electron withdrawing groups to the allene fluorenyl group precludes CT interactions.

prisms, mp: thermal rearrangement occurred upon heating at 191 ${ }^{\circ} \mathrm{C}$ (DSC), IR (Nujol) $2201(\mathrm{C} \equiv \mathrm{C}), 1939(\mathrm{C}=\mathrm{C}=\mathrm{C}), 1676,1639$ $(\mathrm{C}=\mathrm{O}) \quad \mathrm{cm}^{-1} ; \mathrm{UV}\left(\mathrm{CHCl}_{3}\right) \lambda_{\max } / \mathrm{nm}(\varepsilon) 241$ (47900), 251 (47400), 259 (57600), 312 (21200); ${ }^{1} \mathrm{HNMR}\left(300 \mathrm{MHz}, \mathrm{CDCl}_{3}\right.$ ) $\delta 6.43-7.89(\mathrm{~m}, 24 \mathrm{H}), 3.71(\mathrm{~s}, 3 \mathrm{H}), 3.61(\mathrm{~s}, 3 \mathrm{H})$. Anal. Calcd for $\mathrm{C}_{46} \mathrm{H}_{30} \mathrm{O}_{4}$ (646.73): C, 85.43; H, 4.68\%. Found: C, 85.53; H, 4.62\%. 1f: pale-yellow prisms, mp: thermal rearrangement occurred upon heating at $178{ }^{\circ} \mathrm{C}$ (DSC), IR (Nujol) $2211(\mathrm{C} \equiv \mathrm{C}), 1932$ $(\mathrm{C}=\mathrm{C}=\mathrm{C}), 1644,1595(\mathrm{C}=\mathrm{O}) \mathrm{cm}^{-1} ; \mathrm{UV}\left(\mathrm{CHCl}_{3}\right) \lambda_{\max } / \mathrm{nm}(\varepsilon)$ 241 (57300), 260 (74100), 312 (25600); ${ }^{1} \mathrm{H}$ NMR (300 MHz, $\left.\mathrm{CDCl}_{3}\right) \delta$ 6.79-7.90 (m, 24H), $3.70(\mathrm{~s}, 3 \mathrm{H}), 3.60(\mathrm{~s}, 3 \mathrm{H})$. Anal. Calcd for $\mathrm{C}_{46} \mathrm{H}_{30} \mathrm{O}_{4}$ (646.73): $\mathrm{C}, 85.43 ; \mathrm{H}, 4.68 \%$. Found: $\mathrm{C}$, 85.38 ; $\mathrm{H}, 4.71 \%$. 1g: pale-yellow prisms, $\mathrm{mp}$ : thermal rearrangement occurred upon heating at $192{ }^{\circ} \mathrm{C}$ (DSC), IR (Nujol) 2206 $(\mathrm{C} \equiv \mathrm{C}), 1939(\mathrm{C}=\mathrm{C}=\mathrm{C}), 1657,1626(\mathrm{C}=\mathrm{O}) \mathrm{cm}^{-1}$; UV $\left(\mathrm{CHCl}_{3}\right)$ $\lambda_{\max } / \mathrm{nm}(\varepsilon) 242$ (46200), 259 (59200), 301 (44200); ${ }^{1} \mathrm{H}$ NMR
(300 MHz, $\left.\mathrm{CDCl}_{3}\right) \delta 6.39-7.86(\mathrm{~m}, 24 \mathrm{H}), 3.74(\mathrm{~s}, 3 \mathrm{H}), 3.71(\mathrm{~s}$, $3 \mathrm{H})$. Anal. Calcd for $\mathrm{C}_{46} \mathrm{H}_{30} \mathrm{O}_{4}$ (646.73): C, 85.43; H, $4.68 \%$. Found: C, 85.41; H, 4.59\%. 1h: pale-yellow prisms, mp: thermal rearrangement occurred upon heating at $189^{\circ} \mathrm{C}$ (DSC), IR (Nujol) $2201(\mathrm{C} \equiv \mathrm{C}), 1940(\mathrm{C}=\mathrm{C}=\mathrm{C}), 1683,1648(\mathrm{C}=\mathrm{O}) \mathrm{cm}^{-1}$; UV $\left(\mathrm{CHCl}_{3}\right) \lambda_{\max } / \mathrm{nm}(\varepsilon) 259$ (75400), 303 (24400), 315 (23600); ${ }^{1} \mathrm{HNMR}\left(300 \mathrm{MHz}, \mathrm{CDCl}_{3}\right) \delta 6.80-7.89(\mathrm{~m}, 24 \mathrm{H})$. Anal. Calcd for $\mathrm{C}_{44} \mathrm{H}_{24} \mathrm{Cl}_{2} \mathrm{O}_{2}$ (655.57): C, 80.61; $\mathrm{H}, 3.69 \%$. Found: $\mathrm{C}$, 80.47 ; H, 3.65\%. 1i: pale-yellow prisms, mp: thermal rearrangement occurred upon heating at $175{ }^{\circ} \mathrm{C}$ (DSC), IR (Nujol) 2201 $(\mathrm{C} \equiv \mathrm{C}), 1940(\mathrm{C}=\mathrm{C}=\mathrm{C}), 1683,1648(\mathrm{C}=\mathrm{O}) \mathrm{cm}^{-1} ; \mathrm{UV}\left(\mathrm{CHCl}_{3}\right)$ $\lambda_{\max } / \mathrm{nm}(\varepsilon) 260$ (70900), 301 (21000), 315 (19900); ${ }^{1} \mathrm{H} \mathrm{NMR}$ $\left(300 \mathrm{MHz}, \mathrm{CDCl}_{3}\right) \delta 6.80-7.89(\mathrm{~m}, 24 \mathrm{H})$. Anal. Calcd for $\mathrm{C}_{44} \mathrm{H}_{24} \mathrm{Cl}_{2} \mathrm{O}_{2}$ (655.57): C, 80.61; H, 3.69\%. Found: C, 80.75; $\mathrm{H}$, $3.60 \%$. 1j: pale-yellow prisms, $\mathrm{mp}$ : thermal rearrangement occurred upon heating at $198^{\circ} \mathrm{C}(\mathrm{DSC}), \mathrm{IR}$ (Nujol) $2213(\mathrm{C} \equiv \mathrm{C}), 1922$ 
$(\mathrm{C}=\mathrm{C}=\mathrm{C}), 1662,1646(\mathrm{C}=\mathrm{O}) \mathrm{cm}^{-1} ; \mathrm{UV}\left(\mathrm{CHCl}_{3}\right) \lambda_{\max } / \mathrm{nm}(\varepsilon)$ 260 (108000), 316 (29700), 351 (4200); ${ }^{1} \mathrm{HNMR}(300 \mathrm{MHz}$, $\left.\mathrm{CDCl}_{3}\right) \delta$ 6.93-7.84 (m, 24H). Anal. Calcd for $\mathrm{C}_{44} \mathrm{H}_{24} \mathrm{Cl}_{2} \mathrm{O}_{2}$ (655.57): C, 80.61; H, 3.69\%. Found: C, 80.53; H, 3.73\%. 2a: pale-yellow prisms, mp: thermal rearrangement occurred upon heating at $204{ }^{\circ} \mathrm{C}$ (DSC), IR (Nujol) 2211 (C $\left.\equiv \mathrm{C}\right), 1922$ $(\mathrm{C}=\mathrm{C}=\mathrm{C}), 1672,1637(\mathrm{C}=\mathrm{O}) \mathrm{cm}^{-1} ; \mathrm{UV}\left(\mathrm{CHCl}_{3}\right) \lambda_{\max } / \mathrm{nm}(\varepsilon)$ 260 (87200); ${ }^{1} \mathrm{HNMR}\left(300 \mathrm{MHz}, \mathrm{CDCl}_{3}\right) \delta 7.05-7.86(\mathrm{~m}$, 24H). Anal. Calcd for $\mathrm{C}_{44} \mathrm{H}_{24} \mathrm{Cl}_{2} \mathrm{O}_{2}$ (655.57): C, 80.61; $\mathrm{H}$, $3.69 \%$. Found: C, $80.80 ; \mathrm{H}, 3.45 \%$. 3a: yellow prisms, mp: thermal rearrangement occurred upon heating at $174{ }^{\circ} \mathrm{C}$ (DSC), IR (Nujol) $2204(\mathrm{C} \equiv \mathrm{C}), 1936(\mathrm{C}=\mathrm{C}=\mathrm{C}), 1671,1638(\mathrm{C}=\mathrm{O}) \mathrm{cm}^{-1}$; UV $\left(\mathrm{CHCl}_{3}\right) \lambda_{\max } / \mathrm{nm}(\varepsilon) 264$ (75400); ${ }^{1} \mathrm{HNMR}(300 \mathrm{MHz}$, $\left.\mathrm{CDCl}_{3}\right) \delta$ 7.15-7.92 (m, 24H). Anal. Calcd for $\mathrm{C}_{44} \mathrm{H}_{24} \mathrm{Cl}_{2} \mathrm{O}_{2}$
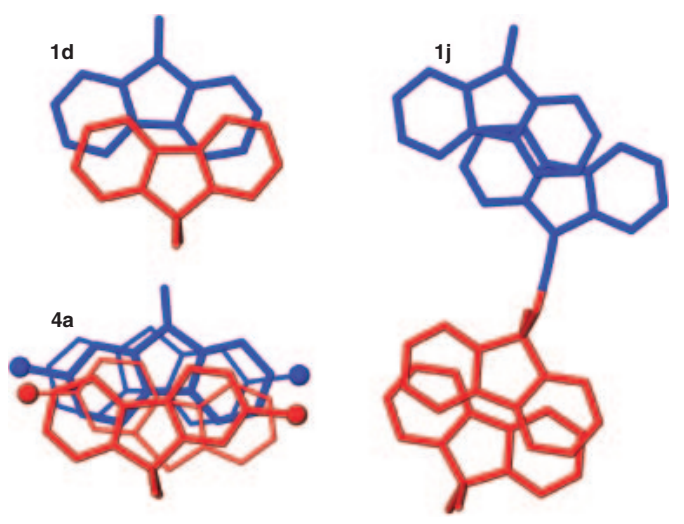

Fig. 5. Overlap of fluorenyl $\pi$ systems in $\mathbf{1 d}$, (top left), $\mathbf{1} \mathbf{j}$ (right), and $\mathbf{4 a}$ (bottom left; major and minor components depicted with thick and thin lines respectively). Red $=$ allene terminus and blue $=$ alkyne terminus.
(655.57): C, 80.61; H, 3.69\%. Found: C, 80.55; H, 3.80\%. 4a: pale-yellow prisms, mp: thermal rearrangement occurred upon heating at $193{ }^{\circ} \mathrm{C}$ (DSC), IR (Nujol) 2205 (C $\left.\equiv \mathrm{C}\right), 1933$ $(\mathrm{C}=\mathrm{C}=\mathrm{C}), 1672,1636(\mathrm{C}=\mathrm{O}) \mathrm{cm}^{-1} ; \mathrm{UV}\left(\mathrm{CHCl}_{3}\right) \lambda_{\max } / \mathrm{nm}(\varepsilon)$ 262 (122000); ${ }^{1} \mathrm{HNMR}\left(300 \mathrm{MHz}, \mathrm{CDCl}_{3}\right) \delta 7.10-7.89(\mathrm{~m}$, 24H). Anal. Calcd for $\mathrm{C}_{44} \mathrm{H}_{24} \mathrm{Cl}_{2} \mathrm{O}_{2}$ (655.57): C, 80.61; $\mathrm{H}$, $3.69 \%$. Found: C, 80.73 ; H, 3.59\%. 4b: yellow needles, mp: thermal rearrangement occurred upon heating at $194{ }^{\circ} \mathrm{C}$ (DSC), IR (Nujol) $2203(\mathrm{C} \equiv \mathrm{C}), 1930(\mathrm{C}=\mathrm{C}=\mathrm{C}), 1672,1636(\mathrm{C}=\mathrm{O}) \mathrm{cm}^{-1}$; $\mathrm{UV}\left(\mathrm{CHCl}_{3}\right) \lambda_{\max } / \mathrm{nm}(\varepsilon) 264$ (87000); ${ }^{1} \mathrm{HNMR}(300 \mathrm{MHz}$, $\left.\mathrm{CDCl}_{3}\right) \delta$ 7.10-8.02 (m, 24H). Anal. Calcd for $\mathrm{C}_{44} \mathrm{H}_{24} \mathrm{Br}_{2} \mathrm{O}_{2}$ (744.47): C, 70.99; H, 3.25\%. Found: C, 70.77; H, 3.31\%. 5a: pale-yellow prisms, mp: thermal rearrangement occurred upon heating at $264{ }^{\circ} \mathrm{C}$ (DSC), IR (Nujol) $2211 \quad(\mathrm{C} \equiv \mathrm{C}), 1941$ $(\mathrm{C}=\mathrm{C}=\mathrm{C}), 1681,1637(\mathrm{C}=\mathrm{O}) \mathrm{cm}^{-1} ; \mathrm{UV}\left(\mathrm{CHCl}_{3}\right) \lambda_{\max } / \mathrm{nm}(\varepsilon)$ 265 (89100); ${ }^{1} \mathrm{HNMR}\left(300 \mathrm{MHz}, \mathrm{CDCl}_{3}\right) \delta 7.21-7.93(\mathrm{~m}$, 24H). Anal. Calcd for $\mathrm{C}_{44} \mathrm{H}_{22} \mathrm{Cl}_{4} \mathrm{O}_{2}$ (724.46): $\mathrm{C}, 72.95 ; \mathrm{H}$, $3.06 \%$. Found: C, $72.87 ; \mathrm{H}, 3.00 \%$. 5b: yellow needles, mp: thermal rearrangement occurred upon heating at $227{ }^{\circ} \mathrm{C}$ (DSC), IR (Nujol) $2208(\mathrm{C} \equiv \mathrm{C}), 1945(\mathrm{C}=\mathrm{C}=\mathrm{C}), 1668,1638(\mathrm{C}=\mathrm{O}) \mathrm{cm}^{-1}$; $\mathrm{UV}\left(\mathrm{CHCl}_{3}\right) \lambda_{\max } / \mathrm{nm}(\varepsilon) 267$ (106000), 347 (4600); ${ }^{1} \mathrm{HNMR}$ (300 MHz, $\left.\mathrm{CDCl}_{3}\right) \delta$ 7.21-8.06 (m, 24H). Anal. Calcd for $\mathrm{C}_{44} \mathrm{H}_{22} \mathrm{Br}_{4} \mathrm{O}_{2}$ (902.26): C, 58.57; H, 2.46\%. Found: C, 58.39; H, $2.56 \%$.

Crystal Structure Analysis: Crystals of $\mathbf{1 d}, \mathbf{1 j}$, and $\mathbf{4 a}$ suitable for single-crystal X-ray diffraction experiments were grown by slow evaporation of solutions of $\mathbf{1 d}$ in chloroform, $\mathbf{1} \mathbf{j}$ in acetone, and 4a in ethyl acetate. Data were collected on an EnrafNonius Kappa CCD diffractometer at $123 \mathrm{~K}$ using graphite-monochromated Mo K $\alpha$ radiation $\left(\lambda=0.71073 \AA, 1^{\circ} \varphi\right.$ and $\omega$ scans $)$. Structures were solved by direct methods using the program SHELXS-97 ${ }^{5}$ and refined by a full-matrix least squares refinement on $F^{2}$ using the programs SHELXL- $97^{6}$ and XSeed. ${ }^{7}$ All non-hydrogen atoms of $\mathbf{1 d}$ and $\mathbf{1} \mathbf{j}$ (as its acetone solvate) were refined

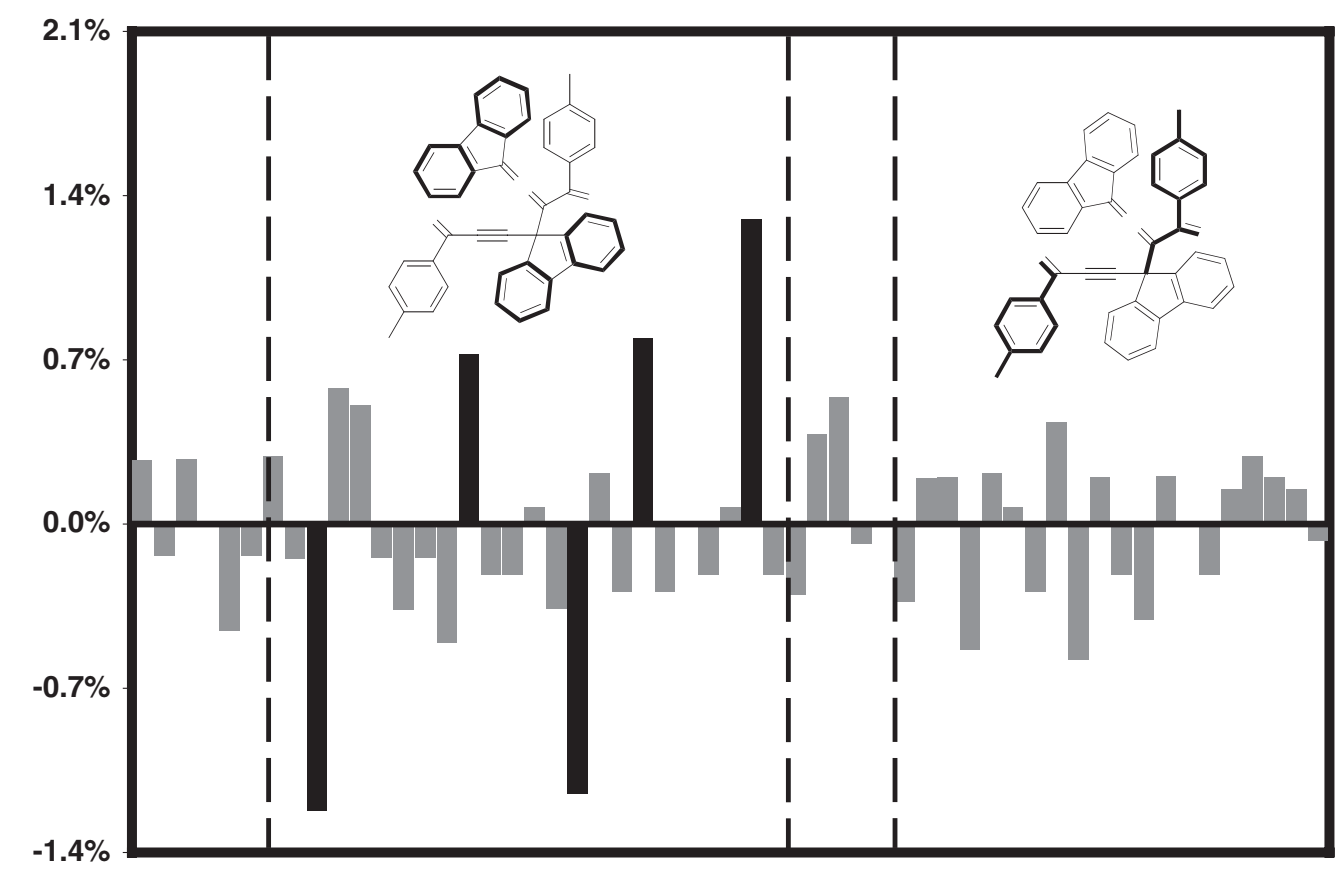

Fig. 6. Percentage change in bond lengths of $\mathbf{1 d}$ in coloured and uncoloured forms. Negative and positive values represent bond lengths that are apparently shorter and longer, respectively, in the coloured (light) form. Dark bars represent differences greater than $0.6 \%$. The greatest differences are noted in the bond lengths of the fluorenyl aromatic rings. 
anisotropically. Hydrogen atoms were inserted in geometrically determined positions with temperature factors fixed at 1.2 times that of the parent atom (1.5 times for methyl group hydrogen atoms). Two datasets were collected for $\mathbf{1 d}$, one with the crystal protected from light and a second after the crystal had been transformed to its green form. In the "light" data collection, the crystal was continuously irradiated so as to avoid bleaching.

The crystal of $\mathbf{4 a}$ (as its ethyl acetate solvate) was protected from light during data collection. While simple anisotropic refinement of non-hydrogen atoms of $\mathbf{4 a}$ led to an acceptable model, a close analysis of electron density difference maps revealed a disorder of the halofluorenyl moieties of $\mathbf{4 a}$; these were modeled over two positions with $80: 20 \%$ occupancy. This model refined well, and the non-hydrogen atoms of the major component $(80 \%)$ of the host were refined anisotropically, while those of the minor component $(20 \%)$ were refined isotropically with aromatic rings constrained to a regular hexagonal geometry. Hydrogen atoms were inserted in geometrically determined positions with the temperature factors fixed at 1.2-times that of the parent atom. Highly disordered ethyl acetate was refined as a group of partially occupied atomic positions totaling one half ethyl acetate molcule per molecule of $\mathbf{4 a}$.

Crystal data for 1d: $\mathrm{C}_{46} \mathrm{H}_{30} \mathrm{O}_{2}, \quad M_{\mathrm{r}}=614.70$, triclinic, space group $P \overline{1}$. Dark: $a=10.0990(3), \quad b=11.7779(3)$, $c=15.1285(5) \quad \AA, \quad \alpha=101.502(1), \quad \beta=104.139(1), \quad \gamma=$ $105.101(1)^{\circ}, V=1616.83(8) \AA^{3}, Z=2, D_{\text {calcd }}=1.263 \mathrm{~g} \cdot \mathrm{cm}^{-3}$, $\mu(\mathrm{Mo} \mathrm{K} \alpha)=0.076 \mathrm{~mm}^{-1} .7457$ Unique reflections, with 3565 $I>2 \sigma(I), R$ indices $[I>2 \sigma(I)] R_{1}=0.0622, w R_{2}=0.1091$, GoF on $F^{2}=0.988$ for 433 refined parameters and 0 restraints. Light: $a=10.0963(3), b=11.7928(3), c=15.1396(6) \AA, \alpha=$ 101.470(1), $\beta=104.226(1), \gamma=105.108(2)^{\circ}, \quad V=1618.97(9)$ $\AA^{3}, Z=2, D_{\text {calcd }}=1.261 \mathrm{~g} \cdot \mathrm{cm}^{-3}, \mu(\mathrm{Mo} \mathrm{K} \alpha)=0.076 \mathrm{~mm}^{-1}$. 5905 Unique reflections, with $2992 I>2 \sigma(I), R$ indices $[I>$ $2 \sigma(I)] R_{1}=0.0588, w R_{2}=0.1096$, GoF on $F^{2}=0.990$ for 435 refined parameters and 0 restraints.

Crystal data for $\mathbf{1 j}: \mathrm{C}_{44} \mathrm{H}_{24} \mathrm{O}_{2} \mathrm{Cl}_{2} \cdot\left(\mathrm{C}_{3} \mathrm{H}_{6} \mathrm{O}\right), M_{\mathrm{r}}=713.61$, triclinic, space group $P \overline{1}, \quad a=10.7444(3), \quad b=13.2792(4)$, $c=14.8200(6) \quad \AA, \quad \alpha=74.848(1), \quad \beta=69.793(2), \quad \gamma=$ $66.884(2)^{\circ}, V=1805.53(10) \AA^{3}, Z=2, D_{\text {calcd }}=1.313 \mathrm{~g} \cdot \mathrm{cm}^{-3}$, $\mu(\mathrm{MoK} \alpha)=0.223 \mathrm{~mm}^{-1} .5553$ Unique reflections, with 3180 $I>2 \sigma(I), R$ indices $[I>2 \sigma(I)] R_{1}=0.0507, w R_{2}=0.0987$, GoF on $F^{2}=0.982$ for 471 refined parameters and 0 restraints.

Crystal data for $4 a: \mathrm{C}_{44} \mathrm{H}_{24} \mathrm{O}_{2} \mathrm{Cl}_{2} \cdot 0.5\left(\mathrm{C}_{4} \mathrm{H}_{8} \mathrm{O}_{2}\right), M_{\mathrm{r}}=699.58$, triclinic, space group $P \overline{1}, a=9.4802(2), b=9.7267(3), c=$ 20.1801(6) $\AA, \alpha=90.572(2), \beta=98.611(2), \gamma=108.532(1)^{\circ}$, $V=1741.16(8) \AA^{3}, Z=2, D_{\text {calcd }}=1.334 \mathrm{~g} \cdot \mathrm{cm}^{-3}, \mu(\mathrm{MoK} \alpha)=$ $0.230 \mathrm{~mm}^{-1}$. 6485 Unique reflections, with $3516 I>2 \sigma(I), R$ indices $[I>2 \sigma(I)] R_{1}=0.0854, w R_{2}=0.2418$, GoF on $F^{2}=$ 0.952 for 495 refined parameters and 0 restraints.
Crystallographic data have been deposited with Cambridge Crystallographic Data Centre as supplementary publication no. CCDC 254804-254807. Copies of the data can be obtained free of charge via www.ccdc.cam.ac.uk/conts/retrieving.html (or from the Cambridge Crystallographic Data Centre, 12, Union Road, Cambridge, CB2 1EZ, UK; Fax: +44 1223 336033; or deposit@ccdc.cam.ac.uk).

\section{References}

1 "Photochromism: Molecules and Systems," ed by H. Durr and H. Bouas-Laurent, Elsevier, Amsterdam (1990); "Organic Photochromic and Thermochromic Compounds," ed by J. C. Crano and R. J. Guglielmetti, Plenum Press, New York (1999); M. Irie, Chem. Rev., 100, 1685 (2000).

2 a) S. Kobatake, S. Kuma, and M. Irie, Bull. Chem. Soc. Jpn., 77, 945 (2004). b) S. Kobatake and M. Irie, Bull. Chem. Soc. Jpn., 77, 195 (2004). c) Y. Yokoyama, Y. Kurimoto, Y. Saito, M. Katsurada, I. Okada, Y. T. Osano, C. Sasaki, Y. Yokoyama, H. Tukada, M. Adachi, S. Nakamura, T. Murayama, T. Harazono, and T. Kodaira, Chem. Lett., 33, 106 (2004). d) M. Taneda, K. Amimoto, H. Koyama, and T. Kawato, Org. Biomol. Chem., 2, 499 (2004). e) K. Tanaka, Y. Yamamoto, and M. R. Caira, CrystEngComm, 6, 1 (2004). f) K. Tanaka, Y. Yamamoto, H. Takano, and M. R. Caira, Chem. Lett., 32, 680 (2003). g) H. Fukuda, K. Amimoto, H. Koyama, and T. Kawato, Org. Biomol. Chem., 1, 1578 (2003). h) P. Naumov, A. Sekine, H. Uekusa, and Y. Ohashi, J. Am. Chem. Soc., 124, 8540 (2002). i) O. Godsi, U. Peskin, M. Kapon, E. Natan, and Y. Eichen, Chem. Commun., 2001, 2132. j) J. N. Moothy, P. Mal, R. Natarajan, and P. Venugoplan, Org. Lett., 3, 1579 (2001). k) K. Tanaka and F. Toda, J. Chem. Soc., Perkin Trans. 1, 2000, 873. 1) K. Amimoto, H. Kanatomi, A. Nagakari, H. Fukuda, H. Koyama, and T. Kawato, Chem. Commun., 2000, 870. m) H. Yoshikawa and S. Nishikiori, Chem. Lett., 2000, 142. n) K. Tanaka, T. Watanabe, and F. Toda, Chem. Commun., 2000, 1361. o) S. Kobatake, M. Yamada, T. Yamada, and M. Irie, J. Am. Chem. Soc., 121, 8450 (1999). p) T. Kawato, H. Kanatomi, K. Amimoto, H. Koyama, and H. Shigemizu, Chem. Lett., 1999, 47. q) J. Harada, H. Uekusa, and Y. Ohashi, J. Am. Chem. Soc., 121, 5809 (1999).

3 K. Tanaka, A. Tomomori, and J. L. Scott, CrystEngComm, 5, 147 (2003).

4 K. Tanaka, A. Tomomori, and J. L. Scott, Eur. J. Org. Chem., 2003, 2035.

5 G. M. Sheldrick, "SHELXS-97," University of Göttingen (1997).

6 G. M. Sheldrick, "SHELXL-97," University of Göttingen (1997).

7 L. J. Barbour, J. Supramol. Chem., 1, 189 (2001). 